\title{
KINETICS OF TNF, IL-6, AND IL-8 GENE EXPRESSION IN LPS-STIMULATED HUMAN WHOLE BLOOD
}

\author{
L.E. DeForge and D.G. Remick
}

Department of Pathology, University of Michigan Medical School, Ann Arbor, MI 481090602

Received November 20,1990

While the production of tumor necrosis factor (TNF) and interleukin-6 (IL-6) in septic shock and other inflammatory states is well established, the role of interleukin-8 (IL-8), a recently described neutrophil chemoattractant and activator, has yet to be fully elucidated. Using lipopolysaccharide (LPS)-stimulated human whole blood as an ex vivo model of sepsis, the kinetics of messenger RNA (mRNA) up-regulation and protein release of these cytokines were examined. Two waves of cytokine gene activation were documented. TNF and IL-6 were induced in the first wave with mRNA levels peaking between 2-4 hours and then rapidly declining. TNF and IL-6 protein peaked at 4-6 hours and then stabilized. IL-8 mRNA and protein were induced in the first wave, reached a plateau between 6-12 hours, and rose again in a second wave which continued to escalate until the end of the 24 hour study. These data demonstrate the complex patterns of cytokine gene expression and suggest that production of early mediators may augment continued expression of $\mathbb{L}-8$ to recruit and retain neutrophils at a site of inflammation.

- 1991 Academic press, Inc.

The morbidity and mortality associated with septic shock are primarily attributable to the endogenous mediators released during the host's response to bacterial LPS (1). One such mediator is TNF, a cytokine released primarily by monocytes and tissue macrophages. TNF is produced in a rapid burst in response to LPS (2), causing direct functional alterations in a wide variety of cell types, as well as inducing the elaboration of a cascade of additional mediators (1). Interleukin-6 (IL-6) is another multifunctional cytokine that is released by myeloid cells and by other cell types such as fibroblasts and endothelial cells (3). Although the full range of activities mediated by IL- 6 is as yet unclear, it is also released relatively early in the immune/inflammatory response and may be beneficial to the host by stimulating lymphocyte differentiation, $B$ cell proliferation, and the production of immunoglobin and hepatic acute phase proteins. Of potential relevance to the pathophysiology of septic shock or local recruitment of neutrophils is a recently characterized protein, termed IL-8, that functions as a neutrophil chemoattractant and activator (4). Originally isolated from the supernatants of LPS-stimulated monocytes (5), this cytokine is now known to be produced by a variety of cell types, including endothelial cells, fibroblasts, hepatocytes, and keratinocytes $(4,6)$, in response to several inflammatory stimuli, including LPS, TNF, and interleukin-1 (IL-1), but not IL-6 (6). 
Studies detailing the role of TNF and $\mathrm{LL}-6$ in vivo have been conducted in experimental animals, but investigations documenting the production of IL-8 have been hampered because the exact homolog in rodents is not known. While routine in vitro cell culture methods have provided some insights into the regulation of IL-8, an alternative approach involves the use of human whole blood (7-9). The ex vivo stimulation of blood with LPS provides a much needed bridge between the in vitro experiments with isolated, cultured cells, and studies with human patients or primates. Use of the whole blood model reduces the confounding factors that may be associated with the isolation of monocytes, such as the adherence-induced expression of cellsurface TNF (7) or TNF mRNA (10). Moreover, whole blood represents a more physiologic environment for examining cytokine production in response to LPS, since the cellular interactions are preserved and the presence of the LPS-binding protein is maintained (11).

In the present study we sought to carefully dissect the kinetics of cytokine expression (both mRNA and protein) in human whole blood in response to LPS. Two distinct waves of cytokine gene activation were apparent, with TNF, IL-6 and IL-8 being produced in an early wave, and IL -8 being produced in a prolonged second wave.

\section{MATERIALS AND METHODS}

Experimental Design. Blood from normal male volunteers was drawn into heparinized syringes (20 U heparin/ml) and placed in sterile $15 \mathrm{ml}$ polypropylene tubes. For each blood sample, a total white blood cell count was obtained using a Coulter counter (Coulter Electronics, Hialeah, FL) and a blood smear was made and stained with Diff-Quik (Scientific Products, McGaw Park, IL). An aliquot of blood $(1 \mathrm{ml})$ was removed from each sample and rapidly processed as described below to serve as the $0 \mathrm{hr}$ time point. The remainder of each blood sample (approximately $10 \mathrm{ml}$ ) was adjusted to $10 \mu \mathrm{g} / \mathrm{ml}$ LPS (Escherichia coli 0111:B4, Sigma Chemical Co., St. Louis, MO) using a $200 \mu \mathrm{g} / \mathrm{ml}$ LPS stock solution. The blood was then placed on a rotator in a $37^{\circ} \mathrm{C} \mathrm{CO}_{2}$ incubator. Control blood samples without added LPS were also incubated. A $1 \mathrm{ml}$ aliquot of blood was removed from each sample at several time points and processed immediatcly. Each aliquot was centrifuged at $600 \mathrm{xg}$ for $5 \mathrm{~min}$, the plasma removed, diluted 1:5 with RPMI 1640 media (Whitaker Bioproducts, Walkersville, MD) containing 1\% fetal calf serum, and stored at $-20^{\circ} \mathrm{C}$ for later analysis. The buffy coat was then removed from the top of the packed red blood cclls and the contaminating red cells were lysed with $0.82 \%$ $\mathrm{NH}_{4} \mathrm{Cl}$. The leukocytes were pelleted by centrifugation at $2000 \mathrm{x}$ g for $5 \mathrm{~min}$, dissolved in 0.3 $\mathrm{ml}$ of an RNA extraction buffer (25 mM Tris, pH 8.0, $4.2 \mathrm{M}$ guanidine isothiocyanate, $0.5 \% \mathrm{~N}$ laurosarcosine, and $0.1 \mathrm{M} 2$-mercaptoethanol), and stored at $-20^{\circ} \mathrm{C}$.

Bioassays and ELISA. Plasma TNF levels were measured as previously described $(12,13)$ using the WEHI 164 subclone 13 cell line, the gift of Dr. Anders Waage, University of Trondhcim, Norway. The B-9 cell line (the gift of Dr. Jack Gauldie, McMaster University, Hamilton, Ontario) was used to assess IL-6 concentrations (14). The plasma IL-8 concentrations were determined using a recently-developed ELISA (15) capable of detecting $<100 \mathrm{pg} / \mathrm{ml}$ IL- 8 . The assay was performed similarly to a previously described LLISA for TNF developed in our laboratory (16). Other cytokines (recombinant human [rh] TNF, rh IL-6, rh IL-1 $\beta$ ) and other proteins in the same gene family (connective tissue activating peptide III, platelet factor 4 , neutrophil activating peptide 2 , and $g r o /$ melanoma growth stimulating activity [kindly provided by Dr. Andreas Huber with the permission of Dr. Alfred Walz]) were tested in this assay and found not to cross-react. The number of monocytes $(\mathrm{MO}) / \mathrm{ml}$ was calculated for each blood donor from the total and differential white cell counts. The cytokine assays were normalized to represent $1 \times 10^{6} \mathrm{MO}$ and results from the 10 donors expressed as mean $\pm \mathrm{SEM}$. 
Northern Blot Analysis. Messenger RNA levels were assessed by Northern blot analysis using our previously described techniques and oligonucleotide probes (17). The blots were hybridized with the ${ }^{32}$ P-5' end-labeled 42 mer oligonucleotide for $\beta$-actin (16). After autoradiograms were obtained, the blots were sequentially stripped (by heating at $80^{\circ} \mathrm{C}$ in a $1 \%$ glycerol solution for 1 $\mathrm{hr}$ ), reprobed, and autoradiographed using the following ${ }^{32} \mathrm{P}-5$ ' end-labeled probes: IL-8 $30 \mathrm{mer}$ (18); IL-6 30 mer 5'-GGT-GAG-TGG-CTG-TCT-GTG-TGG-GGC-GGC-TAC-3' (19); and TNF 25 mer (16). Autoradiograms were scanned with a laser densitometer (LKB Ultroscan XL). The results were normalized to represent equivalent RNA loading in each lane based on the intensity of the actin bands, and the intensity of each lane was then expressed as a percentage of the band of maximal intensity on each blot. The results for all 10 blots were subsequently compiled, expressed as mean \pm SEM.

\section{RESULTS}

Consistent with its purported role as a proximal mediator in septic shock $(1,2)$, the induction of TNF mRNA was very rapid, reaching 56\% of maximum at 1 hour post-LPS challenge and peaking between 2 and 4 hour (Fig. 1A). TNF mRNA levels essentially returned to baseline, unstimulated levels by 8 hours. Lagging slightly behind the mRN $\Lambda$ expression, the plasma TNF concentrations increased in a linear fashion to reach a peak at the 4 hour time point $\left(558.3 \pm 60.6 \mathrm{ng} / \mathrm{ml} / 10^{6}\right.$ monocytes $\left.[\mathrm{MO}]\right)$. Over the remaining time interval, the plasma TNF slowly decreased to a level of $353.7 \pm 49.2 \mathrm{ng} / \mathrm{ml} / 10^{6} \mathrm{MO}$ at the 24 hour time point. The plasma TNF concentrations (not corrected to represent $1 \times 10^{6} \mathrm{MO} / \mathrm{ml}$ ) are shown in Table 1 . Samples from the 4,6 , and 8 hour time points were run in the WEHI assay in the presence of a rabbit polyclonal anti-TNF antibody. Under these conditions, the cytotoxicity of the samples was completely neutralized, thus verifying that the measured activity was in fact due to TNF alone (data not shown).

Relative to TNF, IL-6 gene expression and bioactivity were delayed by 1-2 hours (Fig. 1B). After the 1 hour time point, IL-6 mRNA levels showed rapid kinetics of induction, reaching a peak at 4 hours and returning to control levels at 8 hours. Maximal IL- 6 bioactivity lagged behind both the peak TNF bioactivity and the peak IL- 6 mRN $\Lambda$ by 2 hours. Increasing sharply after the 2 hour time point, IL-6 levels reached a plateau at 6 hours $\left(5.5 \pm 1.7 \mathrm{ng} / \mathrm{m} / 10^{6}\right.$ MO). Uncorrected IL-6 levels are shown in Table 1.

IL-8 gene expression and protein release, in contrast, showed a markedly different pattern of regulation (Fig. 1C). IL-8 mRNA levels increased to approximately $30 \%$ of the maximum over the first 4 hours and then remained at this level until the 12 hour time point. Subsequently, the mRNA levels increased rapidly, reaching a maximum at 24 hours. The appearance of IL- 8 in the plasma followed a similar time course. After lagging behind mRNA expression during the initial 4 hours, the IL- 8 levels reached a plateau of approximately $20 \mathrm{ng} / \mathrm{ml} / 10^{6} \mathrm{MO}$ at the 8 and 


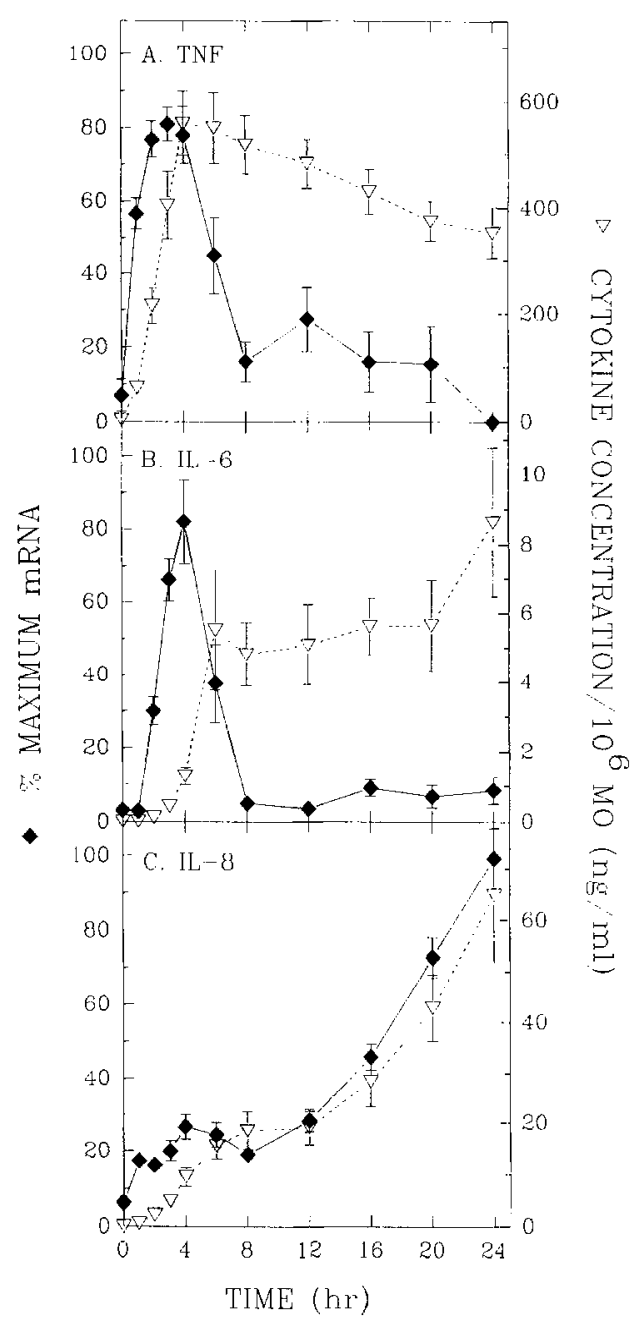

Figure 1. Kinetics of TNF, IL-6, and IL-8 mRNA expression and protein release in LPSstimulated human whole blood. Blood from normal male volunteers $(n=10)$ was stimulated with $10 \mu \mathrm{g} / \mathrm{ml}$ LPS. At the indicated time points, the plasma was analyzed for TNF, IL-6, and $\Pi$-8. The values were adjusted to reflect $1 \times 10^{6}$ monocytes (MO), and are expressed as mean \pm SEM. Total RNA was extracted from the leukocytes and subjected to Northern blot analysis. The autoradiograms were scanned by laser densitometry, and the results were normalized to represent equivalent RNA loading based on the intensity of the actin bands. The compiled results are expressed as \% maximum intensity \pm SEM.

12 hour time points and thereafter increased very rapidly. The IL- 8 concentration at the 24 hour time point was $64.8 \pm 13.0 \mathrm{ng} / \mathrm{mV} / 10^{6} \mathrm{MO}$, and, consistent with the IL-8 $\mathrm{mRNA}$ profile, did not appear to be reaching a plateau (see Tablc 1 for uncorrccted IL-8 concentrations).

The dramatic differences in the kinetics of cytokine mRNA are readily evident in autoradiograms of a single representative blot sequentially probed for TNF, IL-6, IL-8, and $\beta$ actin (Fig. 2). TNF and IL-6 mRNA were under tight regulation as suggested by the rapid kinetics of their induction and disappearance. The levels of IL-8 mRNA, however, continued to increase throughout the entire time course. 
Table 1. Measured TNF, חL-6 and IL-8 levels, uncorrected for the number of monocytes/ml

\begin{tabular}{|c|c|c|c|}
\hline $\begin{array}{l}\text { Incubation } \\
\text { Time } \\
\text { (hr) }\end{array}$ & $\begin{array}{l}\text { TNF }(\mathrm{ng} / \mathrm{ml}) \\
\text { Mean } \pm \text { SD } \\
\text { (Range) }\end{array}$ & $\begin{array}{l}\mathrm{IL}-6(\mathrm{ng} / \mathrm{ml}) \\
\text { Mean } \pm \text { SD } \\
\text { (Range) }\end{array}$ & $\begin{array}{l}\mathrm{IL}-8(\mathrm{ng} / \mathrm{ml}) \\
\text { Mean } \pm \mathrm{SD} \\
\text { (Range) }\end{array}$ \\
\hline 4 & $\begin{array}{l}230.3 \pm 90.2 \\
(100.5-383.3)\end{array}$ & $\begin{array}{l}0.6 \pm 0.4 \\
(0.1-1.4)\end{array}$ & $\begin{array}{c}4.0 \pm 3.1 \\
(1.4-11.9)\end{array}$ \\
\hline 6 & $\begin{array}{l}225.6 \pm 88.4 \\
(99.6-438.0)\end{array}$ & $\begin{array}{l}2.5 \pm 2.6 \\
(0.4-9.8)\end{array}$ & $\begin{array}{c}6.3 \pm 4.0 \\
(3.3-15.8)\end{array}$ \\
\hline 24 & $\begin{array}{l}139.0 \pm 45.6 \\
(74.6-224.2)\end{array}$ & $\begin{array}{l}3.8 \pm 3.2 \\
(0.5-12.7)\end{array}$ & $\begin{array}{l}26.3 \pm 19.9 \\
(11.0-81.0)\end{array}$ \\
\hline
\end{tabular}

Whole blood from normal male donors $(\mathrm{n}=10)$ was stimulated with $10 \mu \mathrm{g} / \mathrm{ml}$ LPS and plasma TNF, IL-6 and IL-8 concentrations were measured. The time points resulting in maximal TNF, IL-6, and IL-8 concentrations are shown.

A control study was performed to examine cytokine release from whole blood incubated under identical conditions but in the absence of added LPS. Very low concentrations of these cytokines were detected. Between 3 and 24 hours of incubation, the average release of TNF, IL6 , and IL-8 in the absence of LPS represented $<0.4,<0.003$, and $<4.5 \%$, respectively, of the

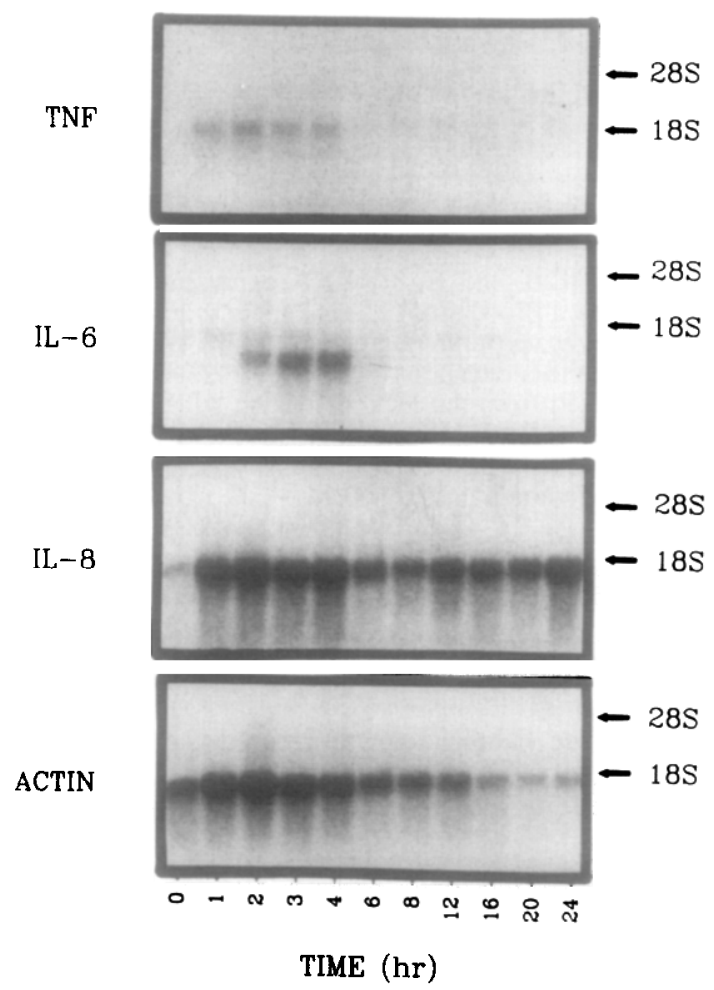

Figure 2. Autoradiograms of a representative Northern blot sequentially probed for TNF, IL-6, $\mathrm{IL-8}$, and $\beta$-actin. Whole blood was stimulated with $10 \mu \mathrm{g} / \mathrm{ml} \mathrm{LPS.} \mathrm{Total} \mathrm{leukocyte} \mathrm{RNA} \mathrm{was}$ extracted at the indicated time points and subjected to Northern blot analysis. 
release measured in the presence of LPS. In addition, this kinetics study has been repeated, and, while the relative concentrations of the cytokines has been found to vary somewhat, the patterns of release were very consistent.

\section{DISCUSSION}

This ex vivo model of sepsis provides a window to observe the kinetics of human cytokine production after LPS stimulation. Relative to one another, the peak in TNF levels ( 4 hour time point) was found to precede the maximal IL-6 levels ( 6 hour time point) by approximately 2 hours. This is in agreement with what has been observed both in clinical and experimental studies $(20,21)$, and may be explained by the ability of TNF, in addition to LPS, to induce IL-6 production (21). In contrast, IL-8 demonstrated a completely different profile of gene expression and protein secretion. These results are consistent with the prolonged expression of IL-8 mRNA and protein which has been observed in isolated monocytes, endothelial cells, and keratinocytes in response to stimuli including LPS, TNF, IL-1, and gamma-interferon $(18,22,23)$.

These marked differences in the kinetics of cytokine production undoubtedly provide a reflection of the functional differences of these mediators. TNF has been characterized as a proximal mediator of the response to LPS, with its rapid production inducing regulatory changes in a wide variety of cell types as well as initiating the release of a cascade of other mediators $(1,4)$. The role of IL-6 in sepsis is less clear, but appears to constitute a signal which stimulates lymphocyte growth and differentiation and induces the production of antibody and hepatic acute phase proteins. IL- 8 , in contrast, possesses a very different spectrum of functions. It has been characterized as a neutrophil chemoattractant and activator and has more recently been found to possess the apparently anti-inflammatory function of preventing the adhesion of neutrophils to endothelium (24). The unusual profile of IL-8 release, with the IL-8 mRNA levels and protein reaching a plateau between 4 and 12 hours and then rising, may reflect these diverse functions, or alternatively may represent a response to multiple stimuli for IL- 8 release. LPS and TNF both elicit IL-8 production from monocytes, suggesting that the second wave of IL-8 production may be induced by the earlier wave of TNF. Studies are underway to investigate this possibility. appreciated. The human IL-6 probe was graciously provided by Dr. Steven Kunkel. 


\section{REFERENCES}

1. Beutler, B., and Cerami, A. (1989) Ann. Rev. Immunol. 7, 625-655.

2. Remick, D.G., Strieter, R.M., Lynch, J.P., III, Nguyen, D., Eskandari, M., and Kunkel, S.L. (1989) Lab. Invest. 60, 766-771.

3. Le, J., and Vilcek, J. (1989) Lab. Invest. 61, 558-602.

4. Matsushima, K., and Oppenheim, J.J. (1989) Cytokine 1, 2-13.

5. Yoshimura, T., Matsushima, K., Tanaka, S., Robinson, E.A., Appella, E., Oppenheim, J.J., and Leonard, E.J. (1987) Proc. Natl. Acad. Sci. USA 84, 9233-9237.

6. Baggiolini, M., Walz, A., and Kunkel, S.L. (1989) J. Clin. Invest. 84, 1045-1049.

7. Hofsli, E., Lamvik, J., Nissen-Meyer, J. (1988) Scand. J. Immunol. 28, 435-441.

8. Desch, C.E., Kovach, N.L., Present, W., Broyles, C., and Harlan, J.M. (1989) Lymphokine Res. 8, 141-146.

9. Steiter, R.M., Remick, D.G., Ham, J.M., Colletti, L.M., Lynch, J.P., III, and Kunkel, S.L. (1990) J. Leukocyte Biol. 47, 366-370.

10. Haskill, S., Johnson, C., Eierman, D., Becker, S., and Warren, K. (1988) J. Immunol. 140, 1690-1690.

11. Wright, S.D., Ramos, R.A., Tobias, P.S., Ulevitch, R.J., and Mathison, J.C. (1990) Science 249, 1431-1433.

12. Eskandari, M.K., Nguyen, D.T., Kunkel, S.L., and Remick, D.G. (1990) Immun. Invest. 19 , 69-79.

13. Espevik, T., Nissen-Meyer, J. (1986) J. Immunol. Methods 95, 99-105.

14. Aarden, L.A., DeGroot, E.R., Schaap, O.L., and Lansdorp, P.M. (1987) Eur. J. Immunol. 17, 1411-1416.

15. DeForge, L.E., and Remick, D.G. Immun. Invest., in press.

16. Nguyen, D.T., Eskandari, M.K., DeForge, L.E., Raiford, C.L., Strieter, R.M., Kunkel, S.L., and Remick, D.G. (1990) J. Immunol. 144, 3822-3828.

17. Kunkel, S.L., Spengler, M., May, M.A., Spengler, R., Larrick, J., and Remick, D. (1988) J. Biol. Chem. 263, 5380-5384.

18. Strieter, R.M., Kunkel, S.L., Showell, H.J., Remick, D.G., Phan, S.H., Ward, P.A., and Marks, R.M. (1989) Science 243, 1467-1469.

19. May, L.T., Helfgott, D.C., and Sehgal, P.B. (1986) Proc. Natl. Acad. Sci. USA 83, 89578961.

20. Waage, A., Brandtzaeg, P., Halstensen, A., Kierfulf, P., and Espevik, T. (1989) J. Exp. Med. 169, 333-338.

21. Shalaby, M.R., Waage, A., Aarden, L., and Espevik, T. (1989) Clin. Immunol. Immunopathol. 53, 488-495.

22. Yoshimura, T., Matsushima, K., Oppenheim, J.J., and Leonard, E.J. (1987) J. Immunol. 139, 788-793.

23. Barker, J.N.W.N., Sarma, V., Mitra, R.S., Dixit, V.M., and Nickoloff, B.J. (1990) J. Clin. Invest. 85, 605-608.

24. Gimbrone, M.A., Jr., Obin, M.S., Brock, A.F., Luis, E.A., Hass, P.E., Hebert, C.A., Yip, Y.K., Leung, D.W., Lowe, D.G., Kohr, W.J., Darbonne, W.C., Bechtol, K.B., and Baker, J.B. (1989) Science 246, 1601-1603. 